\title{
JESUS AS JOSHUA, MOSES EN DAWIDIESE MESSIAS IN MATTEUS ${ }^{1}$
}

\author{
Andries van Aarde \\ Departement Nuwe Testamentiese Wetenskap \\ Universiteit van Pretoria
}

\begin{abstract}
The article argues that Matthew's story is about God who sent Jesus as a Joshua figure from Egypt as Moses' successor to save Israel. As Davidic Messiah and second Moses, Jesus (Joshua) healed all of Israel. Healing in this context is to be released from "political" stress. Matthew's story is about a choice of leadership. This choice concretized in either the people's acknowledgement of 'Inoous ("Joshua") as the savior of all of Israel from their sins or rather in killing him and letting their future children share the responsibility for his blood (Mt 27:25). This message is communicated in the context of opposing scribes who defamed Jesus as someone who annulled the Torah. The aim of the paper is to reflect on Mt 1:21c as the vocational opening verse of Matthew's story, on a "relational contextual" interpretation of the concept "salvation, and the relatedness of "salvation" to "healing".
\end{abstract}

\section{Inleiding}

'n Mens kan Matteus se "evangelie" as 'n apologetiese verhaal tipeer wat die "geskiedenis" oorvertel van hoe God Josua van Egipte af as Moses se opvolger gestuur het om Israel te red. Dit is 'n politieke storie oor 'n leierskapskeuse. Die retoriek van die intrige hang van mense se gehoorsaamheid af. Sal hulle, aan die een kant, luister na die stem van 'n skrifgeleerde, wat 'n dissipel van die hemelse koninkryk geword het, om hulle van beide die "ou Moses" en die "nuwe Moses" te onderrig? Of, sal hulle aan die ander kant verkies om slegs daardie konvensies te gehoorsaam wat volgens die skrifgeleerdes egte Mosaiëse tradisies is? Hierdie keuse neem vorm aan óf in die mense se erkenning van Joshua '(Inбoûs) as die "tweede" Moses en Dawidiese Messias, aan wie God opdrag gegee het om die hele Israel van hulle sondes te verlos, óf om hom eerder dood te maak en toe te laat dat hulle toekomstige kinders medeverantwoordelik is vir sy bloed (Matt 27:25).

Om so 'n lesing van die Evangelie van Matteus te demonstreer, word in hiedie artikel gefokus op (1) die betekenis van die naam Jesus (Joshua) in die "openingsvers", (2) 'n "relasioneel-kontekstuele" benadering tot die interpretasie van die begrip "verlossing" en (3) die verstaan van "verlossing" as "genesing".

1. Hierdie artikel word opgedra aan 'n besondere vriend, professor dr Josephus Henricus Adriaan (Sjef) van Tilborg, gebore Tilburg, 10 April 1939 en gesterf Nijmegen, 22 Mei 2003. Sjef van Tilborg was priester missionaris van het heilig hart (msc) en hoogleraar in exegese van het Nieuwe Testament aan de theologische faculteit, Katkolieke Universiteit Nijmegen, Nederland. Hy was die barmhartige vriend van vreemdelinge en vir meer as 'n dekade tot en met sy dood 'n akademiese ouerfiguur en 'n geesgenoot van die skrywer van hierdie artikel. In Nijmegen was Sjef se hart, kapel en huis die ruimte waar 'n persoonlike katarsis in die periode Mei tot Oktober 2001 in heling verander is. 


\section{Die 'roepingsvers'}

Die openingsverse van 'n narratief is dikwels bepalend vir die verdere ontwikkeling van die plot (kyk Perry (1979/1980:35-64, 311-364; Powell 1992:195-199). Volgens Warren Carter

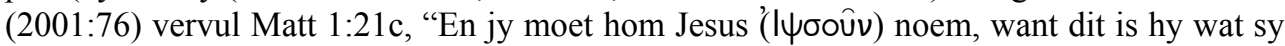

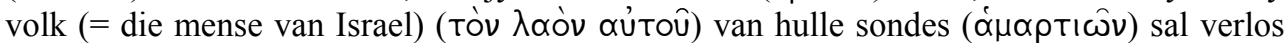
( $\sigma \omega ́ \sigma \varepsilon l) ", 2$ só 'n primêre rol. Hierdie openingsvers van die Matteus-evangelie verleen dwarsdeur die hele werk vorm aan die lesers/hoorders se verwagtings, vrae en begrip ten opsigte van Jesus as reddersfiguur (vgl Carter 2001:76). Die engel se aankondiging aan Josef, die goddelik-aangewese vader van die kind Jesus, in hierdie openingsvers is 'n soort

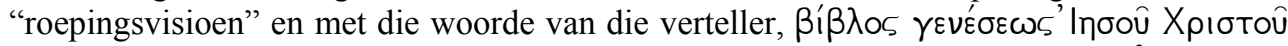

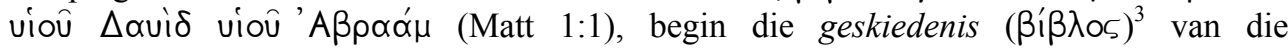
hoofkarakter Jesus. Die boustene van die komposisie van hierdie geskiedenis is:

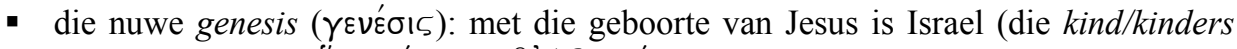

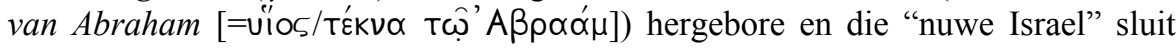
diegene in wat voorheen uitgesluit was van die Jerusalemse tempel (kyk Matt 3:7$10)$

- die messias (Xрıбто5), die "seun van Dawid" as "populêre" (gebore vanuit die populus) koning wat afkomstig is van die nederige Betlehem en nie van die imperiale Jerusalem nie (kyk Matt 2:1-6);

- die verlosser Josua ('Inбoûs) wat die sagmoediges die land laat erf (Matt 5:5; 4:1217; 23-25; vgl Brawley 2003): hierdie "verlosser" word in Jerusalem as die oorwinnaar, die kosmiese verlosser-koning, die Seun van die Mens (Matt 1:17; 28:18; vgl Waetjen 1976a:49-52), geopenbaar en deur die uitverkorenes (die lewendes en die dooies) as God-met-ons verkondig (Matt 27:51-54; 28:20; 1:23; kyk Van Aarde 1998:16-26; vgl Waetjen 1976b:205-230).

Matt 1:21c is ' $\mathrm{n}$ soort profesie oor die grootsheid van hierdie pasgebore koning. Dit is soortgelyk aan die aankondiging van die geboorte van die Persiese verlosser-koning Kores deur Herodotus (Hist 1.107-8), en van Alexander die Grote, die goddelike held van die Grieke, deur Cicero (Div 1.23.47). In 'n Grieks-Romeinse konteks voldoen sulke aankondigings aan die voorskrifte van die progymnasmata vir die skryf van 'n encomium (=lofrede) (kyk Neyrey 1998:90-105). Hermogenes (Rhetores Graeci II.14.8-15.5) onderrig byvoorbeeld sy studente om in 'n encomium met die persoon se herkoms en geboorte te begin. Volgens Hermogenes, behoort die skrywer te vertel "watter wonderbaarlike gebeurtenisse, soos drome of tekens of iets soortgelyks, tydens die geboorte voorgekom het." Quintilianus (Inst Orat 3.7.10-18) leer dat wat voor die geboorte plaasgevind het, ook aangeteken moet word, soos profesieë wat "toekomstige grootsheid voorspel". Suetonius (Vesp 5; Tit 2) se lofverklarings oor die geboorte en toekoms van die keisers Vespianus en Titus dien as voorbeeld hiervan. Plutarchus (Rom 2.4) verwys ook na Romulus, die "stigter" van die "ewige stad Rome" (kyk Rand 1943) en Suetonius (Aug 94; Tib 14) na die eerste twee Romeinse keisers Augustus en Tiberius as verlossers van die hele wêreld (kyk Taylor [1931] 1981). Hierdie figure is deur die gode vir politieke en keiserlike heerskappy bestem(vgl Klauck [1995/1996] 2000:289-302).

2. Die aangehaalde frases in Afrikaans is die skrywer se vertaling van die oorspronklike in die primêre en sekondêre bronne, tensy anders vermeld.

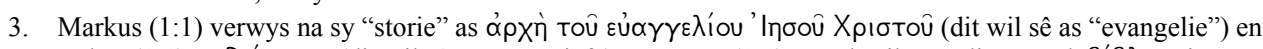

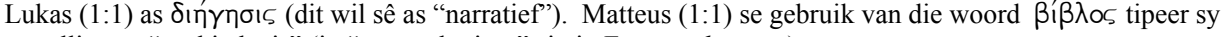
vertelling as "geskiedenis" (in "narratologiese" sin in Frans as histoire). 
In Seneca (kyk Eden 1984:73) se satire oor die vergoddeliking van keiser Claudius (Seneca, Apocolocyntosis 13.12) (kyk Ball 1902:231-232; Eden 1984:139; Schönberger 1990:54), het hy spottenderwys gesê dat die waarheid by monde van die "magi" (="wyses"; in Latyn: mathematicos) kom. Die feit dat Claudius se voortydige geboorte as moontlike oorsaak van sy fisieke gebrek aangevoer kon word, het daartoe gelei dat sy geboorte nie aangekondig is nie; volgens Seneca kon dit tot gevolg gehad het dat sy bestaan geïgnoreer kon word en dat hy doodgemaak kon word (Seneca, Apocolocyntosis 8.3)! ${ }^{4}$

Matteus is insgelyks met die lastering van Jesus gekonfronteer en met sy "geskiedenis" van Jesus" teken hy apologie aan. Sinagogale skrifgeleerdes het navolgers van Jesus daarvan beskuldig dat hulle dit gewaag om na sy dood te beweer dat hy (wat volgens hulle buite die eg gebore is en wat as 'n uitgeworpene en as 'n krimineel gekruisig is) Israel se verlosser-koning is - gebore en opgewek deur God - wat die koers van Israel se geskiedenis tot voordeel van almal omgeswaai het. Hierdie algemene voorstelling van 'n "verlosser-koning" vanuit die Hellenisties-Semitiese en Grieks-Romeinse wêreld werp lig op Matteus se siening van Jesus se geboorte as die aanvang van God se verlossing van Israel (kyk Luz 1985:102, 106).

In 'n groter mate nog spruit die primêre intertekstuele analogieë uit verwysings na die wonderbaarlike geboorte van Moses in Josefus se Antiquitates (2.205-206, 210-211, 215 216) en Pseudo-Philo ${ }^{5}$ se Liber Antiquitatum Biblicarum ${ }^{6}$ (9:1-10) (kyk Bloch ${ }^{7}$ 1954, [1955] 1978; Crossan 1968, hersien in 1986, verwerk in 2003). Volgens René Bloch (1978:67) was Jesus, vereer as die Messias, as 'n "tweede Moses" beskou en dit was daarom vanselfsprekend dat Matteus toespelings op die tradisies oor die geboorte van Moses sou gebruik om die tradisies te interpreteer wat met die geboorte van Jesus verband hou. $^{8}$

Dit is nie alleen die latere Rabbynse tradisie (Mek 14.2) $)^{9}$ wat Moses se geboorte (en in die besonder sy naamgewing) met God se verlossing van Israel verbind nie, maar gedurende die tweede helfte van die eerste eeu doen Josephus (waarskynlik 93-94 nC in Rome) dit ook. ${ }^{10}$ Beide Matteus se "roepingsvers" (Matt 1:21c) en sy "epiloog" (Matt

4. Die "goddelike Augustus" (Seneca, Apocolocyntosis 10.1 - divius Augustus), self 'n bloedverwant van Claudius, so vervolg Seneca met sy gespot, vra hoe dit moontlik is dat so 'n persoon 'n god kon word! "Kyk na sy liggaam, gebore toe die gode toornig was!" (Seneca, Apocolocyntosis 11.3 - videte corpus eius dis iratis natum)!

5. Kyk onder andere Harrington (1989:316-324).

6. Pseudo-Philo se Liber Antiquitatum Biblicarum $(L A B)$ word gedateer tussen 70 en $100 \mathrm{nC}$ (Harrington 1989:317). Vir kritiese uitgawes en moderne vertalings van $L A B$, kyk Crossan (2003) en Harrington (1985:297-377). Die Latynse vorn van $L A B$ is nie oorspronklik nie, maar 'n vertaling van die Griekse teks wat weer op 'n Hebreeuse (nie 'n Aramese - Crossan) oorspronklike teks gebaseer is (Harrington 1970:504).

7. Crossan (2003) wys daarop dat René Bloch se inventaris die vroeëre tekste van Josephus en Pseudo-Philo insluit asook latere tekste (die Targum Pseudo-Jonathan [Bloch se Targum van Jerusalem - Crossan], die Dibre ha-Yamin shel Moshe [=Kroniek van Moses], die Sefer ha-Yashar, die Yalqut Shim'oni en die Sefer haZikhronot). Volgens Bloch (1978:60) ken die Rabbynse tradisie twee weergawes van Moses se geboorteaankondiging, naamlik (1) Farao se droom en die wysgere se voorspelling en (2) Miriam se profesie.

8. Vergelyk ook Allison (1993:147-155) se bespreking van die verwysings in b Baba Batra 120a en Eks Rab 1:19 na die herstel van Jogebed se maagdelikheid.

9. Mek 14.2 verwys na Miriam se woorde in Num 13:17 (Jastrow 1975:601).

10. "This child, whose birth has filled the Egyptians with such dread that they have condemned to destruction all the offspring of the Israelites, shall indeed be yours; he shall escape those who are watching to destroy him, and, reared in a marvellous way, he shall deliver the Hebrew race from their bondage in Egypt, and be remembered, so long as the universe shall endure, not by Hebrews alone but even by alien nations" (Jos, Ant 2.210-211; my beklemtoning; vertaling in Crossan 2003 kom uit uit Thackeray et al [1926-1965]). 
28:19-20) is gemodelleer na aanleiding van onder andere die gangbare Moses-tradisisie (kyk bv Meeks 1970:354-371), soos wat dit voorkom in Josephus se woorde in die Antiquitates: "hy sal die Hebreeuse volk verlos" (vgl Jos, Ant 2.210 met Matt 1:21c) en "hy sal deur al die nasies tot die einde van tyd geëer word" [die "nuwe" Israel ingesluit] (vgl Jos, Ant 2.211 met Matt 28:19-20).

Die uitdrukking "om Israel te verlos" in die latere Rabbynse tradisie (bv Mek 14.2, "my

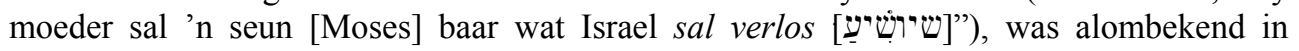
Palestynse kringe in die eerste eeu nC. Matteus se roepingsvers wat op Jesus van toepassing is, getuig van dieselfde tradisie. Miriam se verwysing in Mek 14.2 na haar moeder Jogebed, wat aan 'n toekomstige verlosser (Moses) geboorte sal gee, sinspeel op die woord "Josua"

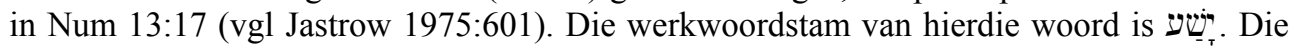
hifil van hierdie woord word in verskeie Ou-Testamentiese tekste as 'n selfstandige

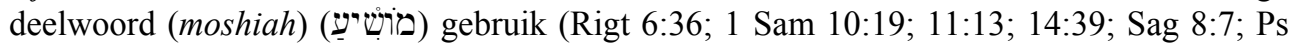
7:11; 17:7). Volgens Köhler \& Baumgartner (1994-2000), beteken die selfstandige deelwoord in hierdie geval "helper" (=verlosser). Hierdie betekenis van moshia kom ooreen met die naam Moses en is 'n woordspeling (paronomasia) op die deelwoord messias

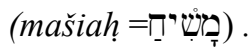

Die woord "messias" het die technicus terminus vir die "gesalfde van Dawid" (of "Dawid se seun") as koning oor die hele Israel (2 Sam 5:1-3) geword. In die Evangelie van Matteus bestaan die messias se verlossingshandeling uit genesing (kyk Duling 1978, 1992). In Ps 118:25 word so 'n paronomasia tussen moshia (=Moses) en messias (=seun van

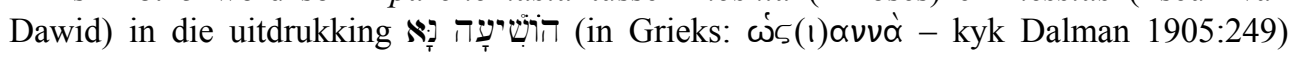
aangetref. Dat hierdie paronomasia aan Matteus bekend was, kan gesien word in sy berig oor Jesus se "koninklike" intog in Jerusalem as die "seun van Dawid", as Israel se helende/reddende messias (Matt 21:14). In Matteus 21:9 haal die evangelis onder andere

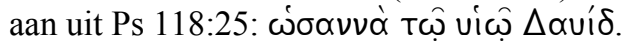

Die afleiding kan gemaak word dat, in die lig van hierdie woordspeling, ${ }^{11}$ Matteus se verhaal oor die verlossing van Israel bestaan uit 'n apologetiese "geskiedenis" ( $\beta$ í $\beta \lambda$ os ...

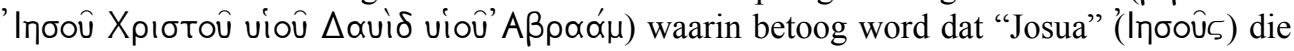
messias is wat God gelegitimeer het as die "tweede Moses" om Israel van hulle sondes te bevry $(\sigma \omega ́ \zeta \omega)$. In Matteus dui die woord $\sigma \omega ́ \zeta \omega$ op "heling/genesing" in 'n allesomvattende sin. Matteus se "soteriologie" is 'n bevestiging van God se soewereiniteit oor die kosmos deur die oorwinning oor die Bose (vgl Carter 2001:76). Matteus se "verlossingsgeskiedenis" is uiteraard nie beperk tot die episodes waar $\sigma \omega ́ \zeta \omega$ voorkom nie. ${ }^{12}$ Die doel van hierdie artikel is om Matteus se "geskiedenis" oor hoe God vir Israel deur Jesus, sy Seun, geheel het, te verduidelik.

My bydrae in hierdie artikel fokus op 'n verduideliking van wat ek 'n "relasioneelkontekstuele" benadering tot Matteus se soteriologie noem. Matteus se "verlossingsboodskap" is dat Jesus Israel se populêre (gebore vanuit die populus) "koninklike" messias is (kyk Horsley \& Hanson 1985). As messias maak Jesus die hele Israel gesond. Heling in hierdie verband beteken om van politieke spanning ${ }^{13}$ bevry te word. Die "politieke" aard

11. Stefan Alkier (2002) verwys daarna as "naamteologie" ('n "theology of names").

12. In 'n ander bydrae gee ek aandag aan die eksegese van al die perikope waarin die woord $\sigma \omega \omega^{\prime} \zeta \omega$ voorkom. .

13. Godsdiens en politiek was sake wat in die Meditereense konteks nou met mekaar verweef is (kyk Sanders 1985:178). Alle byeenkomste van die dorpsmense, of dit nou vir besigheid, politieke en religieuse feeste of gebed was, het op die markplein, in die "stadshuis", of in een van die groter huise plaasgevind. Sodanige samekomste (oftewel "politieke" vergaderings) was dan ook aangewese synagogai (kyk Chiat 1981:50; Meyers 1981:62). Die tempel was ook beide 'n godsdienstige en politieke instelling. Godsdiens was die 
van "stress" het in die Mediterreense konteks het in alle opsigte met met mense se verhouding tot God verband gehou. Dit het ook die familiale en ekonomiese lewe beslissend beïnvloed. Matteus het sy boodskap van "bevryding" gekommunikeer in die konteks van opponerende skrifgeleerdes wat Jesus belaster het as een wat die Tora misken het.

\section{3. 'n 'Relasioneel-kontekstuele' benadering}

Warren Carter $(2000,2001,2002)$ verwerp die idee dat verlossing in die Evangelie van Matteus slegs 'n geestelike fenomeen en nie 'n sosiale een is nie. Dit het 'n cliché geword om te beweer dat Jesus nie 'n politieke messias was soos wat van die seun van Dawid verwag is nie. In die Mediterreense kultuur is politiek en ekonomie onlosmaaklik deel van die kultiese lewe. Die "heilshistoriese" benadering ${ }^{14}$ is by uitstek 'n voorbeeld van 'n anachronistiese vertolking wat neig om die vertikale en horisontale dimensies van verlossing uitmekaar te haal. My benadering kom ooreen met dié van Warren Carter, waarna Richard Horsley verwys as die "relational-contextual" benadering. Horsley (2003:70) koppel sy benadering aan die teologiese begrip "openbaring" en beskryf dit soos volg:

In a relational-contextual and communications approach, revelation would have to be understood relationally-historically. Revelation would be not something new in it self, but would be revelation about the historical situation to people in that situation, for example, the difficult crisis that people are facing, with no resolution apparent. Revelation was that God was acting to change the situation and to change the people in that situation, so that they can act ... (A) relational-contextual approach attempts to discern how the text of (Matthew) references Israelite tradition in a way that provides revelation for people involved in the problematic historical situation. This suggests that the key for modern readers' understanding of Gospel materials is to become as familiar as possible with the Israelite tradition (as well as the context) out of which the historical audience (implied in the text) heard the text.

Jesus as $\beta \propto \sigma ı \lambda \varepsilon u ́ s$ was 'n alternatief vir die keiser as "verlosser" van mense. Die kontras

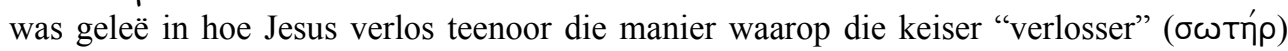
was. Jesus se benadering was dié van 'n herder wat vir sy skape sorg, terwyl die keiser as die veronderstelde beskermer (benefactor) die mense van wie hy lojaliteit geëis het,

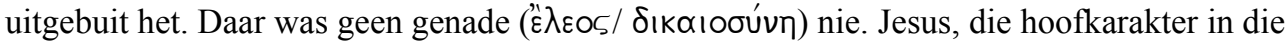
verhaal, is deur die Romeinse owerheid op 'n tipies Romeinse manier van teregstelling doodgemaak. Jesus verkondig die "koninkryk van God" ( $\beta \propto \sigma ı \lambda \varepsilon i ́ \alpha)$. In die lig daarvan dat die Romeinse Ryk die eerste-eeuse wêreld oorheers het, het die betekenis van die woord $\beta \alpha \sigma ı \lambda \varepsilon i \alpha$ op die Romeinse Ryk betrekking gehad. Die $\beta \alpha \sigma ı \lambda \varepsilon i \alpha$ van God wat Jesus verkondig en persoonlik verbeeld en uitleef, het egter in direkte teenstelling met die Romeinse Imperiale Ryk staan (kyk Patterson 1998:60-64; Carter 2001:60-64; Horsley 2003:13-14).

Matteus karakteriseer die leiers van Israel as die bondgenote van Rome. Laasgenoemde verbeeld die Bose en die leiers van Israel is "kinders van die Bose". Hierdie Israelitiese elite was gekant teen Jesus, maar in Matteus vind ons die voorstelling dat hierdie

betekenis wat verleen is aan die wyse waarop politiek en die gesinstelsel in die praktyk gegrond was (Malina \& Rohrbaugh 1992:138).

14. Kyk byvoorbeeld Trilling (1964); Strecker (1966); Walker (1967); Kingsbury (1973); Fankemölle (1974); Cope (1976); Luz (1978); Hagner (1985, [1994] 1996, 2002). 
opposisie ${ }^{15}$ in samewerking met Rome gesien behoort te word. Jesus het in die eerste plek in opposisie teenoor die keiser gestaan. God se soewereiniteit teenoor Rome kom tot uitdrukking in onder andere die wyse waarop God die leiers van Israel "straf" deur Jerusalem op grond van die toedoen van Rome te verwoes. In drie hoofstukke in Matteus oorheers die instrumente van Rome die toneel (Carter 2001:76-77): die kliënte-konings Herodus die Grote (Matt 2) en sy seun Herodus Antipas (Matt 14), en die Romeinse goewerneur Pontius Pilatus (Matt 27). By twee geleenthede beveel Jesus die mense om hulle belasting te betaal. In hierdie perikope tref ons Jesus se visie aan dat God groter is as die mag van Rome (Matt 17:24-27; 22:15-22).

Deur hoofsaaklik Markus en Q as bronne te gebruik, vertel Matteus die Jesus-verhaal oor teen die agtergrond van 'n bepaalde gebeure en ingesteldheid. Die gebeure het betrekking op die sogenoemde "skeiding tussen die sinagoge en die kerk" wat na die vernietiging van die tempel in Jerusalem in $70 \mathrm{nC}$ begin het. Die ingesteldheid het betrekking op die apokaliptiese denke wat Matteus by Markus en van 'n latere weergawe van Q oorgeneem het. Die apokaliptiese verwagting was dat hierdie wêreld in die "finale" Koninkryk van God omskep sou word.

Matteus as skrywer is afkomstig van iewers in noordelike Galilea en suidelike Sirië

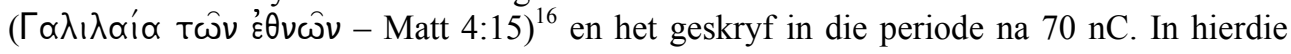
konteks na die vernietiging van Jerusalem en die tempel het konflik geheers tussen die grammateus (skrifgeleerde) Matteus en die skrifgeleerdes van die dorpe, wat besig was om die eerste fase van 'n Farisese "rabbinaat" (bekend as "formative Judaism") te vestig. Die Evangelie van Matteus kan beskou word as 'n produk van skrifgeleerde-aktiwiteit binne die konteks van die heropbou van dorpe tussen die eerste (66-70 nC) en tweede Judese oorlog (132-135 nC), wat op die verwoesting van die tempel in Jerusalem gevolg het.

Die Israelitiese gemeenskappe (dié in Judea en Galilea) het gesukkel om die verlies van Jerusalem en die tempel te verwerk. Aangesien die stad van God en die tempel as "huis van God" nie meer bestaan het nie, moes hulle God se teenwoordigheid binne die konteks van dorpsgemeenskappe ${ }^{17}$ vind. Te midde van Romeinse oorheersing, vernietiging en uitbuiting was skrifgeleerdes aktief betrokke by die heropbou van dorpe. In die dorpe (in Galilea, byvoorbeeld in Kapernaum, Betsaïda en Gorasin - kyk Reed 1995:30; Arnal 2001:19-164) het konflik voorgekom tussen twee groepe skrifgeleerdes: die volgelinge van Jesus wat hom as messias erken het (soos die skrywer van die Evangelie van Matteus) en ander Israeliete wat die tradisionele siening van die messias aangehang het. Die konflik sentreer rondom die interpretasie van die Tora: Jesus as 'n "nuwe Moses" wat die Tora radikaal nuut

15. Wat belangrik is om in Matteus se plot en karaktertekening raak te sien, is die verskynsel dat die Israelitiese volk (dikwels "skare" genoem) van die leiers van Israel onderskei word. Die "skare" wat dikwels voorgestel word as die "verlore huis/skape van Israel" of as "kinders"//die kleintjies"), vorm die "objek" van Jesus se missie en die veronderstelling is dat hulle ook die dissipels se missie sal word. Hierdie "objek" sluit alle "outcasts" (uitgestotenes in Israel asook die heidene) in (kyk Van Aarde 1982:21-34).

16. Kyk ook Schlatter ([1933] 1963) wat van mening is dat Matteus moontlik 'n "etiese rigoris" en 'n verteenwoordiger van die vroegste "Christelike rabbinaat" was.

17. Die Jesus-beweging in Galilea en die werke van vroeg post-70 nC rabbi's (wat deur Horsley 1996:181-184 as die "vroeëre skrifgeleerdes en wyses" bestempel is) kan beskou word as 'n "heroplewing van dorpsgemeenskappe". Nadat die tempel verwoes is, het die Farisese skrifgeleerdes en wyses hulle in plekke soos Jamnia (in Judea), Galilea en Sirië georganiseer. Daar het hulle probeer om die ou waardesisteem van die tempel te dupliseer in huishoudings in die dorpe, veral reëls oor die hiërargie in die samelewing en die reinheidsideologie van die tempel. 'n Soortgelyke aktiwiteit om 'n renaissaince van dorpsgemeenskappe te bewerkstellig, is onder die Jesus-groepe gevind. Die waardesisteem wat hulle ingestel het, was gebaseer op Jesus se alternatiewe verstaan van die Tora. Die verskil in waardesisteme en belange het tot konflik gelei tussen die Farisese skrifgeleerdes en die skrifgeleerdes wat van Jesus se volgelinge was. 
interpreteer of die tradisionele Mosaïese siening, soos deur die vroeëre tempelkultus gereguleer was en nou met selfs meer onverdraagsame rigorisme toegepas is. Skrifgeleerdes in die sinagoges het 'n probleem daarmee gehad dat Jesus as die genesende Seun van Dawid beskou is. Hulle kon nie toegee dat hy Israel se nuwe Moses was nie. Vir hulle het dit nie sin gemaak dat Jesus "die tempel kon vervang" (Matt 12:1-32), terwyl hy weggedoen het met die tempel se reinigingsvoorskrifte, soos wat hy met sy genesingshandeling op die Sabbat gedemonstreer het nie.

Die outeur van die Matteus-evangelie verwys implisiet na homself as 'n skrifgeleerde

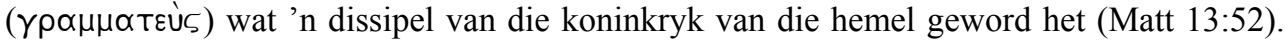
Dit lyk asof Jerusalem en die leierskapskonflik wat daar geheers het, die wêreld was vanwaar hy gekom het. Hierdie "bagasie" wat hy saamgedra het, was waarskynlik gevorm deur die oortuigings van die vroegste Jesus-groep in Jerusalem voordat Jakobus (Jesus se broer) hierdie kultusgroep gedomineer het en Petrus van sy leierskap "onttroon" het. Die volgende elemente in die Matteus-evangelie demonstreer die skrywer se oriëntasie:

- 'n Voorkeur vir Petriniese leierskap (vgl Meier 1983:12-86).

- Antagonisme teen rigiede legalisme (kyk bv Sim 2002:767-783). ${ }^{18}$

- 'n Apokaliptiese passie wat samewerking met Rome verwerp.

- Terughoudendheid om God se boodskap wyer as Jerusalem uit te dra, want dit was God se werk; die profete het dit duidelik gemaak dat die nasies na Jerusalem toe moes kom.

- Geen spanning tussen die "kerk as die eskatologiese herstelde nuwe Israel" en die

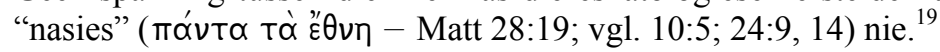

- Die gebruik van die begrip "sonde" (Matt 1:25; 3:6; 18:15) as 'n etiket om die uitsluiting van uitgeworpenes aan te dui. ${ }^{20}$

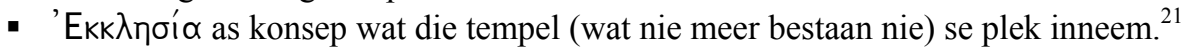

- Die voorheen "uitgeworpene" wat met die Israelitiese volk ("skare" = of óx入oı/ó $\lambda$ גós) geassosieer is. ${ }^{22}$

In Matteus verwys die uitdrukking "verlossing van sonde" na Jesus se helende handeling om "uitgeworpenes" as die "verlore skape van Israel" weer in die "huis van Israel" te

18. Sim (2002:767-783) fokus op onlangse Matteus-studies, soos dié van die Switserse eksegeet Marguerat (1981). Marguerat (1981:212-235) bespreek Matteus se konserwatiewe siening van die Tora. Volgens hom moet dit toegeskryf word aan Matteus se aanvaarding van 'n optimistiese "Joodse" antropologie wat nie 'n radikale siening van sonde voorgehou het nie, altans nie tot die mate dat dit ekstreme libertinisme verhoed het nie.

19. тর́์ was, nou toegang tot God het.

20. Matteus verwys metafories na die "uitgeworpenes" as die "kleintjies/kindertjies" en gebruik uitdrukkings soos

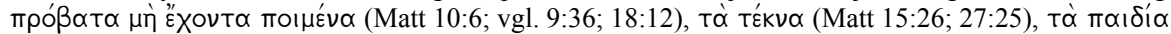

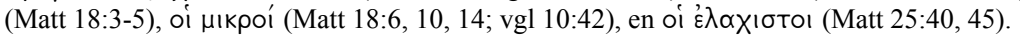

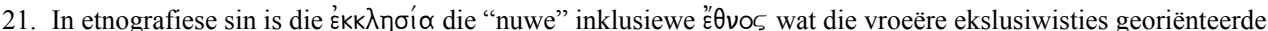
Israel as " "verlore huis van Israel" in.

22. Matteus gebruik die verhouding tussen Jesus (en die twaalf dissipels/apostels) en die "skare" as analogie vir die verhouding tussen die "skrifgeleerde dorpsleiers" en die Israelitiese kleinboere ("peasants") in die

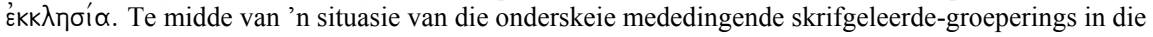
"sinagoges" in Galilese/Siriese dorpe soos Kapernaum, Betsaïda en Gorasin, het Matteus gepoog om die

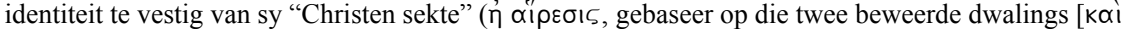

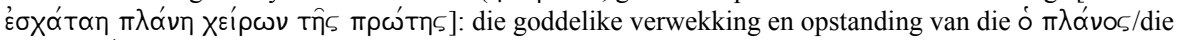

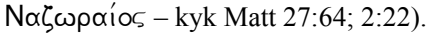


akkommodeer. Hierdie akkommodasie beteken in die konteks van die tempelreligie en sosio-religieuse gebuike van daardie tyd 'n aanvaarding deur ook die "God van Israel".

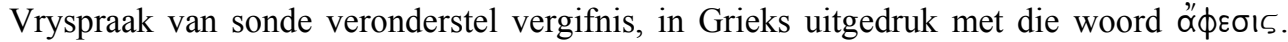

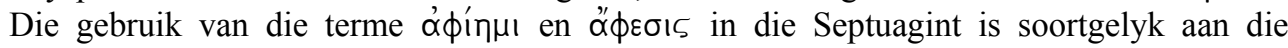
gebruik van die woorde in klassieke Grieks. Die woorde verwys aan die een kant na vergifnis in die godsdienstige of etiese sin, en aan die ander kant word dit in 'n breër sin gebruik. In die Mediterreense kulturele konteks word interpersoonlike verhoudings (nie net tussen mense nie, maar ook tussen God en mense) vanuit 'n "diadiese" perspektief gesien. Dit is 'n hiëragiese patronaatsverhouding tussen 'n beskermheer (patron) en onderdaan (kliënt). In 'n diadiese verhouding verleen die beskermheer vergifnis aan die kliënt as die kliënt ritueel berou het en selfs fisies kompensasie as regstelling van die beskadigde verhouding verskaf. Vergifnis het dan ook betrekking op geestelike en materiële dinge.

In die Nuwe Testament word die term óфínuı gebruik om na die kwytskelding van geldskuld (Matt 18:27, 32), bevryding van aanhouding (Luk 14:18) en vryspraak van sonde (Matt 6:14-15; Mark 2:5-10; 3:28; Luk 7:47-50) te verwys. In die tradisie van die jubeljaar verwys vergifnis na die vrylating van slawe en die kwytskelding van skuld (Lev 25). Vryheid is vir slawe en ander gevangenes aangekondig (Jes 58:6; 61:1-2). In Luk 7:36-50 reflekteer hierdie konsep die jubeljaarvoorstellings van ' $n$ terugkeer tot God soos wat dit in Lev 25 en Jes 61 voorkom, nou apokalipties verstaan as verwysing na "bevryding" aan die einde van die tyd en ter viering van God se heerskappy (kyk Ringe 1985:71).

In Matteus voorsien twee gedeeltes spesifiek die agtergrond om die referensiële betekenis van Jesus se boodskap van vergifnis te begryp: die gelykenis van die onvergewingsgesinde slaaf (Matt 18:21-35) en die vergifnis waarvoor ons in die Onse Vadergebed bid (Matt 6:14-15). In die gelykenis is die sentrale tema die keuse tussen die beleid van die ou orde, soos vergestalt deur beide die heersende Romeinse heerskappy en die tradisionele Israelitiese ervaring, en Jesus se onkonvensionele boodskap oor die heerskappy van God. Wedersydse kwytskelding van skuld beteken dat die nuwe "ekonomie van genade" en vryheid ten opsigte van die ou orde van verslawing en verpligtings, wat op skuld en slawerny uitloop, triomfeer. Deur vergifnis te ontvang en te weier om ander te vergewe, beteken dat 'n mens jouself van God se heerskappy uitsluit (Ringe 1985:76, 77; kyk Crosby 1988:188). Insgelyks in die Onse Vader-gebed is die vryspraak van sonde op die manifestasie van God se heerskappy "op aarde soos in die hemel" gefokus (kyk Ringe 1985:79-80). Hier vind ons 'n voorstelling van God se heerskappy wat 'n alternatief is op die ontmensliking wat die keiser se heerskappy op alle vlakke van die menslike teweeggebring het. Die beeld van God as "koning en vader" wat vrymaak (vergewe) en nie brood uit die mond van mense neem nie maar dit daagliks voorsien, bevestig God se heerskappy van meelewing en liefde. Hierdie "vergifnis" is wederkerend, soos in diadiese verhoudings verwag kan word, en daarom raak die "wederliefde" alle verhoudings en het dit geld sonder uitsondering op die lewens van alle mense. Dit het veral betrekking op die genesing van die gebreke van die sosiale uitgeworpenes, dit wil sê die "verlore skape van Israel”.

\section{Verlossing as genesing}

Die werkwoord $\sigma \omega ́ \zeta \omega$ (wat in in die kanonieke evangelies die meeste in Matteus voorkom) beteken "heling/genesing" in 'n omvattende sin (kyk Foerster 1971:990). Waar die woord in die kanonieke evangelies in verband met fisiese genesing of duiweluitdrywing (in Matt 9:21, 22a, 22b, 14:36) voorkom, kan dit as "gesond maak" of "heel maak" vertaal word (Wilkinson 1998:80). Dit verwys voorts na bevryding van fisiese gevaar of die dood (in 
Matt $8: 25 ; 14: 30 ; 16: 25 ; 27: 40,42 \mathrm{a}, 42 \mathrm{~b}, 49)$. Hierdie verwysings sluit nie die konnotasie van "heling" uit nie. Die vier insidente van bevryding van fisiese gevaar wat in die kruisigingstoneel voorkom, is satiriese verwysings na 'n koning wat ander van hulle siektes, demone en die dood verlos het, maar wat nie daartoe in staat is om homself te verlos nie (kyk Filson 1950:296). Genesing, volgens Matteus is die goddelike verlossing van demoniese magte. In die konteks van daardie tyd, is demone as die antitese van God beskou (kyk Van Aarde 2000:1-19). Verligting van spanning het bevryding van daardie demone beteken. Jesus se genesings kan daarom (vanuit die perspketief van die moderne samelewing en in kontemporêre terme) as bemagtigingshelings gedefinieer word. Jesus het mense wat aan spanning gely het, "bemagtig" en hulle in staat gestel om te oorleef. Hy het nuwe betekenis aan mense se lewens kom gee.

Palestina onder Herodus is deur die Romeine as eiendom van die Romeinse owerheid beskou (ager publicus populi Romani) en was dus "beskikbaar" vir uitbuiting (Oakman 1986:67). In weerwil daarvan dat die Romeine die Israeliete se grond en hulle huweliksmaatreëls (kyk Van Aarde 1995:345-355) gerespekteer het, was uitbuiting en onteiening van grond deel van 'n wrede realiteit. Groot stukke grond is opgekoop en vir persoonlike gewin verhuur of gebruik om die Romeinse leër te onderhou (kyk Fiensy 1991:79). Hierdie keiserlike oorheersing en verdrukking sou noodwendig aanleiding gee tot spanning in die lewe van mense. Dit is daarom logies dat geestesongesteldheid/ duiwelbesetenheid so 'n belangrike plek in die gemeenskap sou inneem. Talle navorsers (kyk Hollenbach 1982:507-588; Myers 1988:141-152; Waetjen 1989:113-119; Davies 1993:2; Crossan 1996:92) het die verband tussen politieke verdrukking en duiwelbesetenheid aangedui. ${ }^{23}$ Om onder sulke omstandighede siek te word, is om 'n potensiële situasie te skep om as "sondaar" gebrandmerk te word. Etikettering was 'n kragtige sosiale wapen waarmee 'n persoon in 'n magsposisie 'n ander skade kon berokken (kyk Malina \& Neyrey 1988:4). Negatiewe etikettering het daartoe gelei dat 'n persoon deur die gemeenskap as "uit sy plek uit" beskou is (kyk Malina \& Neyrey 1991:99).

Mense se ellende is verlig deur 'n "eksterne krag" (God), wat beheer verkry het oor 'n ander (Satan), wat die ellende veroorsaak het. Dit is deur agente bewerkstellig: in die Grieks-Romeinse wêreld die theios aner ('n "held" in die gedaante van 'n god-mens soos Herakles, Asklepius of Appolonius), en in die Israelitiese wêreld, deur gesante van God. Hierdie gesante (profete, konings, priesters) was gevul met die Gees van God. Satan het ook agente in diens gehad. Hierdie agente was daarvoor verantwoordelik dat demone besit van 'n persoon neem. Vir die Israeliete was God se messias die mees prominente agent (vgl 1 Hen 53:3-5; 54:4-6; Tes Levi 18: 12). In die post-monargale tydperk het die messias as 'n heler/geneser gefunksioneer. ${ }^{24}$

Die rede waarom baie mense Jesus gevolg het was omdat hy hulle gesond gemaak het deur hulle demone uit te dryf. Dit is onwaarskynlik dat mense hom gevolg het bloot omdat hy hulle "geroep" het. Die verligting van spanning as gevolg van konflik binne die uitgebreide familie (tot selfs die grens van "Israel as familie" - kyk Neusner 1987:331-361) kon 'n motief gewees het (Davies 1995:81). Sodanige konflik kon deur die disintegrasie

23. Mark 5:1-20 (die besetene van Gerasa) is 'n klassieke voorbeeld ter illustrasie hiervan. Die naam van die demoon, Legio, verwys na Romeinse imperialisme in Palestina en die ekonomiese uitbuiting, politieke verdrukking en sosiale ontwrigting wat daarmee gepaardgegaan het. Deur die bose geeste uit te dryf, hulle in die varke in te stuur en dié in die see te laat val, toon Jesus nie alleen sy mag oor die imperialistiese uitbuiting nie, maar vernietig tegelykertyd die Romeinse legioene se kosvoorraad (Crossan 1996:92-93).

24. Nie almal het gemeen dat Jesus die messias was nie. Jesus se opponente (die Fariseërs) het hom as 'n agent van die Bose, Beëlsebul, beskou (Matt 12:22-32). 
van gesinne en armoede, vanweë militêre besetting en die onteiening van grond, veroorsaak gewees het (Horsley 2003:31-34). Sommige lede van die gesin het as gevolg van spanning siek geword. Mense wat aangetas is, is gemarginaliseer of deur die familie verwerp. Sommige randgroepe, wat probeer het om buite die normale familiekring 'n bestaan te voer, kon die sosio-ekonomiese groep gewees het waarna Josefus gereeld as die "struikrowers" (bandits) verwys het (kyk Horsley 1979:37-63). Hulle het dikwels die enigste hawe vir ander uitgeworpenes gebied. In hulle geledere was ook mense wat ons teëkom in teksverse soos Matt 15:29- 32:64 (NAV) lees:

29. Jesus het daarvandaan vertrek en by die see van Galilea gekom. Hy het teen die berg opgegaan en daar gaan sit.

30. Baie mense het na Hom toe gekom met verlamdes, blindes, gebreklikes, dowes en nog baie ander, en hulle voor Hom neergesit. Hy het hulle gesond gemaak,

31. sodat die menigte hulle verwonder het toe hulle sien dat stommes praat, gebreklikes herstel is, verlamdes loop en blindes sien. En hulle het die God van Israel geprys.

32. Jesus het sy dissipels nader geroep en vir hulle gesê: "Ek kry hierdie mense innig jammer, want hulle is nou al drie dae lank hier by My en hulle het niks om te eet nie. En Ek wil hulle ook nie sonder kos (weg)stuur nie, want hulle kan miskien op pad beswyk."

"Onrein" en "nie-heel" (bv fisies gestremde) mense is beskou as van God vervreem. Hulle was die "sondaars" wat onder die invloed van die demone was. Dit is met verwysing hierna dat Matteus na sommige van die Galileërs verwys as diegene wat in "duisternis woon" (Matt 4:16). Volgens Matteus (wat sy begrip van Jesus se genesingsaktiwiteite van temas in die Hebreeuse Bybel ontwikkel het - bv Jes 8:23-9:2; 58:10), was Jesus se boodskap dat God se koninkryk naby was, vir die randfigure (die uitgeworpenes, die "mense wat in duisternis gelewe het") soos 'n opkomende lig. Hierdie mense was volgens reinigingsgebruike die sosiaal veragtes, wat uit huise verjaag is en wat toegang tot die tempel en sinagoges geweier is. Jesus se wonderwerke was gemik op die uitgeworpenes in Galilea (vgl Theissen [1974] 1983:249). Matteus 4:23-5:4 e v (NAV), is ook 'n voorbeeld van so 'n berig:

23. Hy het toe in die hele Galilea rondgegaan en die mense in hulle sinagoges geleer, die evangelie van die (Hemelse) koninkryk verkondig en elke soort siekte en kwaal onder die volk gesond gemaak.

24. En berigte oor Hom het deur die hele provinsie Sirië versprei. Die mense het toe die siekes met allerhande kwale en pyne, dié wat in die mag van duiwels was, geestelik versteurdes en verlamdes na Hom gebring, en Hy het hulle gesond gemaak.

25. Groot menigtes uit Galilea, Dekapolis, Jerusalem, Judea en van oorkant die Jordaan af het Hom gevolg.

5. Toe Jesus die menigte mense sien, het hy teen die berg opgegaan. Nadat Hy gaan sit het, het sy dissipels na Hom toe gekom,

2. en Hy het hulle geleer en gesê:

3. Geseënd is dié wat weet hoe afhanklik hulle van God is, want aan hulle behoort die koninkryk van die hemel.

4. Geseënd is dié wat treur,want hulle sal vertroos word. 
Hierdie berig toon duidelik dat Jesus nie alleen as 'n heler van siektes opgetree het nie, maar ook as kritikus van die samelewing. Soos Gerd Theissen (1983:251) aandui het moet die die genesings gesien word teen die agtergrond van die gemeenskap wat dit oorvertel. Dit is in 'n sekere sin kollektiewe, simboliese aksies waaardeur ellende verlig is en waaruit mense krag geput het om siekte in hulle gewone lewens deur aksies, wat meer as blote "simboliek" was, te beveg.

Diegene wat ongesteld was, was dié wat arm was, mense wat getreur het. Hierdie werkwoorde word aangetref in die eerste twee saligsprekinge (Matt 5:3-4) wat Matteus se Bergrede (Matt 5:1-7:28) voorafgaan. Dit blyk dat hierdie twee saligsprekinge, en die een oor diegene wat honger en dors is na wat reg is (Matt 5:6), deur Matteus as "godsdienstige deugde eerder as ... sosiale en ekonomiese omstandighede" (Funk \& Hoover 1993:139) geïnterpreteer is. Lukas se weergawe van die saligsprekinge wat "gerig is op die armes, dié wat ween, dié wat honger het", wat uit die Spreuke-Evangelie Q (6:22-23) geneem is, is heel waarskynlik nader aan die oorspronklike. Hulle verteenwoordig nie "vergeestelikings" soos in die geval van Matteus nie, aangesien hulle nie die aanduidings "arm van gees" en "honger en dors na geregtigheid" bevat nie. Wat Matteus doen, moet nietemin nie as asosio-polities geïnterpreteer word nie. ${ }^{25}$ Matteus het 'n "tiperende styl van komposisie" (kyk Theissen 1983:207). Hy som dikwels sy begrip van Jesus se wonderwerke op. Wanneer Matteus godsdienstige deugde by Jesus se uitsprake oor politieke en ekonomiese omstandighede voeg, distansieer hy hom beslis nie van die konkrete sosiale gevolge van Jesus se genesingsaksies nie. Theissen (1983:207), wat fokus op die betekenis daarvan dat Jesus hom tot die sosiale en politieke verstotenes gewend het, beskryf Matteus se metode soos volg: "Die programmatiese opsomming van wonders in (Matt) 4:23-25 gaan die Bergrede vooraf. Daarin word onderrig en genesing met mekaar verbind. Laat die eksegeet nie dít wat Matteus bymekaar gevoeg het, uitmekaar haal nie."

\section{Bevinding}

Matteus se apologetiese "geskiedenis" wat die verhaal oorvertel van hoe God Josua van Egipte af as Moses se opvolger gestuur het om Israel te red, bestaan uit twee sub-plotte. Die eerste van die twee verhaallyne handel oor die opposisie tussen Jesus en die leiers van die tempelkultus. Jesus is inklusief, hulle is eksklusief. Hulle werk saam met Rome, Jesus werk saam met God. Jesus se boodskap word aan die verlore skape van Israel gebring. Die leiers van die tempelkultus is blinde leiers. Hulle lei die skape op 'n dwaalspoor. Die dissipels is

25. Hierdie oortuiging lyk op 'n bewustelike verandering in die standpunt wat ek vroeër sou gehuldig het, naamlik dat ek (soos die Jesus Seminar) sou meen dat Jesus a-polities georiënteerd was. Ek kan verstaan dat kollegas (bv uitgespreek tydens die agelope jaarkongres van die Nuwe-Testamentiese Werkgemeenskap wat gedurende 22-2 Aprl 2003 by die Univeriteit van Natal, Piermaritzburg, plaasgevind het) by my 'n moontlike "standpuntverandering" vermoed. Tog is dit in hierdie geval nie so nie (hoewel ek my mening ten opsigte van ander sake wel verander het). In my boek Fatherless in Galilee (Van Aarde 2001; my beklemtoning in hierdie artikel) het ek in hierdie verband na my ooreenstemming met die Jesus Seminar soos volg verwys: "Jesus is seen as a person from the peasant farming community of Herodian Galilee with an 'apolitical' criticism of the temple and a non-apocalyptic, inclusive, and anti-hierarchical vision of the kingdom of God." Afgesien daarvan dat ek "a-polities" in aanhalingstekens geplaas het, het ek ook verduidelik dat Jesus nie op 'n anakronistiese en etnosentristiese wyse as "polities" in die moderne (bv "demokratiese") sin van die woord gesien behoort te word nie: "Economical and political forces behind modern social dichotomies are often ascribed to the conditions that were presumably present in the world of Jesus or the early church. In other words, ancient pre-industrial documents are being interpreted from the perspective of our present-day societal structures." Daarom is dit ook verstaanbaar dat iemand soos Thomas Wright (1996:78-82) weer die Jesusprofiel van die Jesus Seminar as "socially and politically minded" tipeer. 
ambivalent: hulle is veronderstel om Jesus te ondersteun, maar hulle is geneig om met leiers van die tempelkultus te identifiseer.

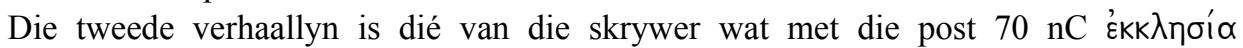
kommunikeer. Ook hier word leiers gevind wat die skrywer (en Jesus) navolg en ander wat onder die druk van die Fariseërs swig. Die allegoriese storie van die brandende stad (Matt 22:1-14) is tekenend van wat hulle lot mag wees. Net soos wat God tussenbeide getree het en Rome gebruik het om Jerusalem, die stad van die samesweerders, te vernietig, net so sal dié persoon apokalipties uit die eindtyd- messiaanse banket gewerp word omdat hy of sy nie die kleed, wat by die heilige bruilof pas, gedra het nie. Dit beteken dat hierdie persoon 'n keuse vir die teenstanders van Jesus uitgeoefen het. Diegene wat getrou gebly het aan die "wet van die messias" wat die "Evangelie van die Koninkryk" is, sal in die teenwoordigheid van die God-met-ons bly (Matt 28:16-20).

\section{BIBLIOGRAFIE}

Alkier, S 2002. Intertextualität: Annäherungen an ein texttheoretischen Paradigma.

Unpublished paper, Matthew Seminar of the Studiorum Novi Testamenti Societas, $57^{\text {th }}$ Annual Meeting, University of Durham, August 6-10, 2002.

Allison, DC, Jr 1993. The new Moses: A Matthean typology. Minneapolis: Fortress.

Arnal, WE 2001. Jesus and the village scribes: Galilean conflicts and the setting of $Q$. Minneaopolis: Fortress.

Ball, AP 1902. The satire of Seneca on the apotheosis of Claudius. New York: The Columbia University Press.

Bloch, R 1954. Quelques aspects de la figure de Moïse dans la tradition rabbinique. Cahiers Sioniens 8, 210-285. Reprinted: in Cazelles, H (ed.) 1955, Moïse, l'homme de l'Alliance, 93-167. Tournai: Desclée. (Special edition of Cahiers Sioniens, nos. 24 of 1954.)

Bloch, R (1955) 1978. Note methodolique pour l'étude de la literature rabbibnique. Recherchesde Science Religieuse 43, 194-227. Reprinted: Methodological note for the study of Rabbinic literature, in Green, WS (ed.) 1978, Approaches to Ancient Judaism, 1:Theory and practice, 51-75, translated by WS Green \& WJ Sullivan. Missoula, MT: Scholars Press for Brown University. (Brown Judaic Studies 1.)

Brawley, RL 2003. Evocative allusions in Matthew. HTS 59(3). (Forthcoming.)

Carter, W 2000. Matthew and the margins: A sociopolitical and religious reading. Maryknoll, NY: Orbis.

Carter, W 2001. Matthew and Empire: Initial explorations. Harrisburg, PA: Trinity. Press International.

Carter, W 2002. Are there imperial texts in the class? Intertextual eagles and Matthean eschatology as lights out time for imperial Rome (Matt 24:27-31). Unpublished paper, Matthew Seminar of the Studiorum Novi Testamenti Societas, $57^{\text {th }}$ Annual Meeting, University of Durham, August 6-10, 2002.

Chiat, MJ 1981. First-century synagogue architecture: Methodological problems, in Gutmann, J (ed.), Ancient synagogues: The state of research, 49-60. Chico, CA: Scholars Press. (Brown Judaic Studies 22.)

Cope, OL 1976. A scribe trained for the kingdom of heaven. Washington, D C: Catholic Biblical Association of America. (CBQMS 5.)

Crossan, JD 1968. Structure and theology of Mt. 1.18-2.23. Cahiers de Joséphologie 16, 119-135. 
1986. From Moses to Jesus: Parallel themes. Bible Review 2(2), 18-27.

1996. Who is Jesus? Answers to your questions about the historical Jesus. New York: Harper Collins.

2003. Virgin mother or bastard child? HTS 59(3). (Forthcoming.)

Crosby, MH 1988. The house of disciples: Church, economics and justice in Matthew. New York: Orbis Books.

Dalman, G 1905. Grammatik der judisch-palestinischen Aramaisch: Nach den Idiomen des palestinischen Talmus des Onkeltargum ind Prophetentragum und des jerusalemischen Targume. Aramaische Dialektproben. Darmstadt: Wissenschaftliche Buchgesellschaft.

Davies, SL 1993. Whom Jesus healed and how. The Fourth $R$ 6(2), 1-11.

- 1995. Jesus the healer: Possession, trance, and the origins of Christianity. New York: Continuum.

Duling, DC 1978. The therapeutic son of David: An element in Matthew's christological apologetic. NTS 24: 392-410.

1992. Matthew's plurisignificant "Son of David" in social science perspective: Kinship, kingship, magic, and miracle. BTB 22, 99-116.

Eden, PT (ed.) 1984. Seneca “Apocolocyntosis.” Cambridge: Cambridge University Press.

Fiensy, DA 1991. The social history of Palestine in the Herodian Period. Lewiston, NY: Edwin Mellen. (Studies in the Bible and early Christianity 20.)

Filson, FV 1950. A commentary on the Gospel according to St Matthew. London: Black.

Foerster, G 1971. s v sw//zw. TDNT 7.

Frankemölle, H 1974. Jahwebund und Kirche Christi: Studien zur Form- und Traditionsgeschichte des "Evangeliums" nach Matthäus. Münster: Aschendorf.

Funk, RW \& Hoover RW (and The Jesus Seminar) 1993. The Five Gospels: The search for the authentic words of Jesus. New York: Macmillan Publishing Company.

Hagner, DA 1985. Apocalyptic motifs in the Gospel of Matthew: Continuity and discontinuity. Horizons in Biblical Theology 7, 53-82.

-(1994) 1996. Matthew's eschatology, in Schmidt, T E \& Silva, M (eds.), To tell the mystery: Essays on New Testament eschatology in honor of Robert G Gundry, 4971. Sheffield: JSOT Press. (JSNT Supplement Series 100.) (Reprinted in SBLSP 35 1996, 163-181.)

2002. Matthew: Apostate, reformer, revolutionary? Unpublished paper, Studiorum Novi Testamenti Societas, $57^{\text {th }}$ Annual Meeting, University of Durham, August 6$10,2002$.

Harrington, DJ 1970. The original language of Pseudo-Philo's Liber Antiquitatum Biblicarum. Harvard Theological Review 63, 503-514.

1985, Pseudo-Philo: A new translation and introduction, in Charlesworth, JH (ed.), The Old Testament Pseudepigrapha, vol 2, 297-377. Garden City, NY: Doubleday.

Harrington, DJ 1989. Birth narratives in Pseudo-Philo's Biblical Antiquities and the Gospels, in Horgan, MP \& Kobelski, PJ (eds.), To touch the text: Biblical and related studies in honor of JA Fitzmyer, 316-324. New York, NY: Crossroad.

Hollenbach, PW 1982. Jesus, demoniacs, and public authorities: A socio-historical study. Journal of the American Academy of Religion 49, 507-588.

Horsley, RA 1979. Josephus and the bandits. Journal of Jewish Studies 10, 37-63.

1996. Archeology, history, and society in Galilee: The social context of Jesus and the rabbis. Valley Forge, PA: Trinity Press International. 
2003. Jesus and the Empire: The Kingdom of God and the new world disorder. Minneapolis: Augsburg Fortress.

Horsley, RA \& Hanson, JS 1985. Bandits, prophets, and messiahs: Popular movements in the time of Jesus. Minneapolis, MN: Fortress.

Jastrow, M 1975. A dictionary of the Targumim, the Talmud Babli and Yerushalmi. New York: The Judaica Press.

Kingsbury, JD 1973. The structure of Matthew's gospel and his concept of salvationhistory. $C B Q 35,451-474$.

Klauck, H-J (1995/1996) 2000. The religious context of early Christianity: A guide to Graeco-Roman religions, translated by B McNeil. Edinburgh: T \& T Clark.

Luz, U 1978. Die Erfüllung des Gesetzes bei Matthäus (Mt 5:17-20). ZThK 75, 398-435. 1985. Das Evangelium nach Matthäus, 1.Teilband: Mt 1-7. Zürich: Benziger Verlag. (EKK 1/1.)

Malina, BJ \& Neyrey JH 1988. Calling Jesus names: The social value of labels in Matthew. Sonoma: Polebridge Press.

1991. Conflict in Luke-Acts: Labelling and deviance theory, in Neyrey, JH (ed.), The world of Luke-Acts: Models for interpretation, 97-124. Peabody, MA: Hendrickson.

Malina, BJ \& Rohrbaugh, RL 1992. Social science commentary on the synoptic gospels. Minneapolis: Fortress.

Marguerat, D 1981. Le Jugement dans l'évangile de Mthieu. Geneva: Labor et Fides.(Le Monde de la Bible 6.)

Meeks, WA 1970. Moses as God and king, in Neusner, J (ed.), Religions in antiquity: Essays in memory of Erwin Ramsdell Goodenough, 354-371. Leiden: Brill.

Meier, JP 1983. Antioch, in Brown, R E \& Meier, J P, Antioch and Rome, 12-86. New York: Paulist.

Meyers, EM 1981. Ancient Gush Halav (Giscala), Palestinian synagogues and the astern Diaspora, in Gutmann, J (ed.), Ancient synagogues: The state of research, 61-78. Chico, CA: Scholars Press. (Brown Judaic Studies 22.)

Myers, C 1988. Binding the strong man: A political reading of Mark's story of Jesus. New York: Orbis.

Neyrey, JH 1998. Honor and shame in the Gospel of Matthew. Louisville, KT: Westminster.

Neusner, J 1987. Israel: Judaism and its social metaphors. Journal of the American Academy for Religion 55, 331-361.

Oakman, D E 1986. Jesus and the economic questions of his day. New York: The Edwin Mellen Press.

Patterson, SJ 1998. The God of Jesus: The historical Jesus and the search for meaning. Harrisburg, PA: Trinity Press International.

Perry, M 1979-1980. Literary dynamics: How the order of a text creates its meaning. Poetics Today 1, 35-64, 311-364.

Powell, MA 1992. The plot and subplots of Matthew's gospel. NTS 38, 187-204.

Rand, EK 1943. The building of eternal Rome. Cambridge, MA: Harvard University Press.

Reed, JL 1995. The social map of Q, in Kloppenborg, JS (ed.), Conflict and invention: Literary, rhetorical, and social studies on the Sayings Gospel Q, 17-36. Valley Forge, Pa: Trinity Press International. 
Ringe, SH 1985. Jesus, liberation, and the Biblical jubilee: Images for ethics and Christology. Philadelphia: Fortress.

Sanders, EP 1985. Jesus and Judaism. Philadelphia: Fortress Press.

Schönberger, O 1990. Lucius Annaeus Seneca-Apocolocyntosis Divi Clavdii: Einführung, Text und Kommentar. Würzburg: Königshausen \& Neumann.

Schlatter, A (1933) 1963. Der Evangelist des Matthäus. Seine Sprache, seine Ziel, seine Selbbeständigkeit: Eine Kommentar zum ersten Evangelium. 6.Auflage. Stuttgart: Calwer.

Sim, DC 2002. Matthew's anti-Paulinism. HTS 58(2), 767-783.

Stanton, G 1992. A Gospel for a new people: Studies in Matthew. Edinburgh: T \& T Clark. Strecker, G 1966. Der Weg der Gerechtigkeit: Untersuchung zur Theologie des Matthäus. 2.Auflage. Göttingen: Vandenhoeck \& Ruprecht.

Thackeray, H St et al 1926-1965. Josephus, 10 vols. Cambridge: Harvard University Press. (LCL.)

Theissen, G (1974) 1983. The miracle stories of the early Christian tradition, translated by F McDonagh, edited by J Riches. Edinburgh: T \& T Clark.

Taylor, LR (1931) 1981. The divinity of the Roman emperor. Reprinted. Chico, CA: Scholars Press.

Trilling, W 1964. Das wahre Israel: Studien zur Theologie des Matthäus-Evangeliums. 2.Auflage. München: Kösel.

Van Aarde, AG 1982. Matthew's portrayal of the disciples and the structure of Matthew 13:53-17:27. Neotestamentica 16, 21-34.

1995. The marriage arrangements in the Jerusalem temple cult in opposition to Christian values (original Afrikaans). Skrif en Kerk 18(2), 345-355. 1998. Matthew 27:45-53 and the turning of the tide in Israel's history. BTB 28(1), 16-26.

2000. Understanding Jesus' healings. Scriptura 18, 1-19. 2001. Fatherless in Galilee: Jesus as child of God. Harrisburg, PA: Trinity Press International.

Waetjen, HC 1976a. The origin and destiny of humanness: An interpretation of the Gospel according to Matthew. San Rafael, CA: Crystal Press. 1976b. The genealogy as the key to the Gospel according to Matthew. JBL 95, 205230.

1989. A reordering of power: A socio-political reading of Mark's gospel. Minneapolis: Fortress.

Wilkinson, J 1998. The Bible and healing: A medical and theological commentary. Edinburgh: Handsel Press. 